\title{
STRATEGI PENGAJARAN BAHASA ARAB DI MI RAKHA AMUNTAI
}

\author{
H. Alfianor, Lc., M.Pd.I \\ Dosen, STIQ Amuntai, Kalimantan Selatan, Indonesia \\ hajialfianorlc@gmail.com
}

\begin{abstract}
Abstrak
Untuk mencapai tujuan pembelajaran bahasa Arab pada materi mufradat tentunya tidak lepas dari perencanaan yang matang. Penggunaan strategi yang tepat akan memudahkan siswa menguasai mufradat. Tujuan riset ini adalah untuk mengeksplorasi tentang bagaimana strategi pengajaran bahasa Arab di MI Rakha Amuntai. Penelitian menggunakan metode kualitatif, dengan teknik observasi, wawancara dan dokumentasi sebagai teknik pengumpulan data, dan teknik Miles dan Huberman yaitu reduksi data, display data dan verifikasi data sebagai teknik analisis datanya. Hasil penelitian ini adalah strategi pengajaran bahasa Arab pada materi mufradat di MI Rakha Amuntai sudah berjalan dengan baik. Hal ini dibuktikan dengan adanya penyusunan perencanaan pelaksanaan pembelajaran dengan baik, setidaknya sudah tersusun dan tergambarkan proses pembelajaran mulai dari pendahuluan, kegiatan inti dan penutup. Namun begitu, dalam perencanaan tersebut belum tergambarkan secara jelas terkait strategi apa yang digunakan, serta langkah-langkahnya juga belum tersusun secara terperinci, begitu juga dengan metode dan medianya. Namun guru terlihat menggunakan strategi bermain peran dan demonstrasi dalam mengajarkan bahasa Arab pada materi mufradat di MI Rakha Amuntai. Secara teoretis dan praktis penelitian ini diharapkan dapat berkontribusi bagi sekolah dan guru agar mempersiapkan rencana pembelajaran dengan sebaik-baiknya, melengkapai komponen-komponen pada perencanaan pelaksanaan pembelajaran, dan menentukan strategi, metode, pendekatan, dan media yang tepat untuk materi pelajaran yang akan disampaikan kepada siswa, sehingga materi menjadi lebih mudah diserap dan kuasai oleh siswa dan tujuan pembelajaran dapat tercapai dengan maksimal.
\end{abstract}

Kata Kunci: Strategi, Pengajaran, Bahasa Arab, MI Rakha Amuntai

\section{PENDAHULUAN}

Bahasa Arab adalah bahasa yang memiliki peranan penting bagi umat Islam. Karena bahasa Arab merupakan bahasa yang digunakan dalam Alquran, al-Hadits, kitab-kitab klasik serta digunakan untuk berkomunikasi. Hal ini sebagaimana yang dikatakan oleh Hasna Qonita Khansa, yang mengatakan bahwa bahasa Arab memiliki peranan yang sangat penting bagi agama Islam, karena bahasa Arab sebagai bahasa komunikasi yang berkaitan dengan agama Islam. Selain itu, Ia juga mengatakan bahwa bahasa Arab merupakan salah satu bahasa asing yang dipelajari di Indonesia, yang tidak hanya diajarkan di pondok pesantren, akan tetapi juga bahasa arab diajarkan di sekolah formal yang negeri maupun yang swasta. Khususnya pada madrasah-madrasah, yang

Al-Madrasah: Jurnal Ilmiah Pendidikan Madrasah Ibtidaiyah

Vol. 6, No. 1, Januari-Maret 2022 
mana bahasa Arab merupakan mata pelajaran wajib serta termasuk dalam mata pelajaran yang diujikan pada akhir madrasah yang bertaraf nasional. ${ }^{1}$

Guru atau pengajar memiliki peran dan tugas utama yaitu menyelenggerakan pengajaran dan pendidikan dengan sebaik mungkin. Menurut Khotijah, agar kegiatan pendidikan dan pengajaran dapat berjalan dengan efektif, tercapai tujuan yang diinginkan dan berjalan dengan baik, maka seorang guru harus mengatahui hakikat kegiatan belajar mengajar. apa yang diajarkan, kepada siapa diajarkan, untuk apa diajarkan, bagaimana cara mengukur keberhasilan, dan bagaimana cara mengajarkan, semua harus diatur dan direncanakan dengan sedemikian rupa (strategi). ${ }^{2}$

Dalam Kamus Besar Bahasa Indonesia (KBBI), strategi adalah rencana yang cermat untuk mencapai suatu sasaran atau suatu tujuan tertentu. ${ }^{3}$ Senada dengan pendapat Bahkan Slameto mengatakan strategi adalah suatu perencanaan tentang cara penggunaan dan pemanfaatan sarana dan potensi yang ada untuk meningkatkan efisiensi dan efektifitas. ${ }^{4}$ Hilda Taba mengatakan bahwa strategi pembelajaran merupakan cara yang diseleksi dan dipilih oleh guru dalam proses belajar mengajar dengan tujuan agar dapat memberikan kemudahan atau jalan menuju tercapaianya suatu rencana atau tujuan pembelajaran. ${ }^{5}$

Strategi merupakan alat yang sangat urgent bagi keberhasilan suatu pengajaran dan Pendidikan. Sebagaimana yang dikatakan oleh Asse dan Nursyam bahwa tanpa adanya strategi yang tepat dan sesuai dengan pengajaran, maka akan mengalami kesulitan untuk mencapai sasaran dan tujuan pengajaran yang diinginkan. strategi merupakan suatu cara kerja umum dan sistematik, terutama dala m mencari kebenaran ilmiah. Dalam kaitannya dengan pengajaran bahasa Arab maka setrategi akan selalu beranjak dari hakikat usaha penyampaian bahan ajar atau materi kepada siswa agar materi itu dipahami dan diterima. Di tangan siapa strategi itu dipegang, maka dituntut kepadanya suatu keterampilan dan kemampuan dalam mengaplikasinnya. Strategi merupakan suatu alat atau yang digunakan sebagai solusi. Dengan Latihan disertai konsentrasi, siapapun akan menjadi ahli serta mampu improvisasinya. Sukses atau tidaknya suatu pembelajaran bahasa Arab dalah ditentukan oleh strategi yang digunakannya. Oleh sebab itu strategilah yang menempati pada posisi terpenting untuk tercapainya cara dan isi dalam mengajarkan bahasa. ${ }^{6}$

${ }^{1}$ Hasna Qunita Khansa', "Strategi Pembelajaran Bahasa Arab," Proseding Konferensi Nasional Bahasa Arab 1, no. 2 (2016): h. 53.

${ }^{2}$ Khotijah Khotijah, "Desain Strategi Pembelajaran Bahasa Arab Di MI," Al-Fathin: Jurnal Bahasa dan Sastra Arab 1, no. 01 (2018): h. 23.

${ }^{3}$ KBBI Offline versi 1.2, t.t.

${ }^{4}$ Slameto, Proses Belajar Megajar Dalam Sistim Kredit Semester (Jakarta: Bumi Aksara, 1991), h. 90.

${ }^{5}$ Suprihadi Saputro, Zainul Abidin, dan I Wayan Sutama, Strategi Pembelajaran, Bahan Sajian Program Pendidikan Akta Mengajar (Malang: Universitas Negeri Malang, 2002), h. 21.

${ }^{6}$ Ahmad Asse dan Nursyam Nursyam, "Strategi Pembelajaran Bahasa Arab di Insutut Agama Islam Negeri Palu," Istiqra: Jurnal Hasil Penelitian 2, no. 2 (2014): h. 453.

Al-Madrasah: Jurnal Ilmiah Pendidikan Madrasah Ibtidaiyah Vol. 6, No. 1, Januari-Maret 2022 
Namun, pada dasarnya bahasa Arab merupakan bahasa asing yang diajarkan di Indonesia. Bahasa Arab menjadi mata pelajaran bagi sekolah formal, meskipun prosinya berbeda dengan kurikulum non formal seperti di pondok pesantren, yang lebih banyak porsi waktu untuk pembelajaran bahasa Arab. Oleh karena itu, pembelajaran bahasa Arab tentunya mengalami berbagai kendala dan problematika dalam mempelajari bahasa Arab tersebut. Menurut Zaenuddin, salah satu masalah yang masih sering dijumpai dalam aktivitas pegajaran bahasa Arab atau bahasa Asing adalah masalah pengayaan, metode, dan strategi pengajaran. ${ }^{7}$

Berdasarkan observasi sementara penulis yang lakukan di MI Rakha Amuntai, penulis jumpai bahwa pembelajaran bahasa Arab berjalan dengan baik, siswa terlihat aktif dalam mengikuti pembelajaran bahasa Arab, pada materi mufradat guru terlihat meragakan atau mendemonstrasikan mufradat yang sedang dipelajari, selain itu guru juga sering bertanya kepada siswa dengan menunjukkan gambar atau suatu benda dan kegiatan yang berkaitan dengan materi mufradat yang telah disampaikannya. Dengan begitu pembelajaran menjadi lebih aktif dan menarik. Namun, berdasarkan wawancara dengan guru tersebut mengatakan bahwa dalam hal perencanaan pelaksanaan pembelajaran untuk penggunaan metode, pendekatan dan strategi tidak dicantumkan dengan rinci, karena menurutnya hal tersebut sifatnya fleksibel. Padahal secara teoretis perencanaan pembelajaran merupakan hal yang sangat penting untuk menunjang kesuksesan pembelajaran. Dengan perencanaan pembelajaran yang jelas, terstuktur dan rinci kemungkinan besar akan memudahkan jalannya pembelajaran dan menghasilkan pembelajaran yang lebih berkualitas.

Berdasarkan hal tersebut, penulis tertarik untuk meneliti lebih lanjut dan lebih mendalam, agar medapatkan data yang lebih komprehensif dan kredibel tentang bagaimana strategi pengajaran bahasa Arab di MI Rakha Amuntai.

\section{METODE PENELITIAN}

Penelitian ini menggunakan metode penelitian kualitatif. Penelitian kualitatif merupakan suatu penelitian yang bertujuan untuk menggambarkan dan menganalisis peristiwa social, fenomena, sikap, persepsi, kepercayaan, dan pemikiran orang secara kelompok maupuan secara individu. Data dan sumber data pada penelitian ini terdiri dari dari data utama (primer) dan data skunder (pendukung). Data utama adalah data yang diambil langsung ke lapangan melalui observasi, dokumentasi dan wawancara. Sedangkan data sekunder diambil dari buku-buku dan hasil penelitian yang relevan. Teknik dokumentasi, pengamatan, dan wawancara sebagai teknik pengumpulan data. Setalah data terkumpul selanjutnya adalah direduksi, didisplay dan ditarik kesimpulan.

\footnotetext{
${ }^{7}$ Asse dan Nursyam, h. 454.
}

Al-Madrasah: Jurnal Ilmiah Pendidikan Madrasah Ibtidaiyah Vol. 6, No. 1, Januari-Maret 2022 


\section{HASIL DAN PEMBAHASAN}

Sesuai dengan Standar Nasional Pendidikan (SNP), standar proses merupakan salah satu standar yang harus dikembangkan. Sebab, standar proses merupakan standar nasional Pendidikan yang ada hubungannya dengan pelaksanaan pembelajaran. Di antara standar proses tersebut adalah adanya perencanaan kegiatan pembelajaran, adanya proses pelaksanaan belajar mengajar/pembelajaran, dan evaluasi atau penilaian hasil pembelajaran. Oleh karena itu, pada pelajaran bahasa Arab dalam mengimplementasi strategi pembelajaran tentunya juga mempetimbangkan dan memperhatikan hal tersebut. Namun, yang menjadi subjek pada penelitian ini adalah satu orang guru bahasa Arab yang mengajar di kelas VI dengan materi mufradat.

Adapun strategi belajar mengajar (pembelajaran) yang berhubungan dengan pendidikan, seorang pengajar tentunya menginginkan hasil belajar yang baik, dan harapan tersebut tentunya tidak hanya sebuah pengharapakan belaka, melaikan dengan suatu usaha yang juga maksimal, salah satunya adalah dengan menerapkan suatu strategi dalam pembelajaran, dengan begitu kemungkinan besar pembelajaran akan berhasil, dan pastinya siswa juga akan mendapatkan prestasi yang baik pula. Menurut Kemp strategi pembelajaran merupakan kegiatan yang harus disusun, direncanakan dan dikerjakan guru dan siswa agar tujuan pembelajaran dapat tercapai dengan efektif dan efisien. ${ }^{8}$

Berdasarkan hasil pengamatan dan interview dengan Guru MI Rakha Amuntai, maka penulis dapat rincikan dan uraikan sebagai berikut: Ketika Guru ditanya, bagaimana anda ketika mengajar bahasa arab terutama materi mufradat dan strategi apa yang anda gunakan?, maka guru tersebut menjawab dengan mengatakan bahwa,

Biasanya sebelum saya mengajar bahasa arab, saya merencanaan pembelajaran bahasa arab dengan menyusun dan menyiapkan RPP terlebih dahulu, nah dengan RPP itu jadinya semakin mudah mengajarnya. Karena di dalam RPP sudah saya susun mulai dari tujuan pembelajaran, materinya, alokasi waktu, indikatornya, langkah-langkah pembelajarannya, sampai penilaian. Tapi untuk strategi, metode dan media tidak saya cantumkan ke dalam RPP, karena menurut saya itu nanti bisa fleksibel ketika pelaksanaan pembelajaran berlangsung. Jadi saya biasanya mengajar, ada pendahuluan, kegiatan inti atau penyampain materi dan di akhir ada penilaian. Dan saya biasanya ketika mengajar bahasa arab terutama materi mufradat itu biasanya mengajarnya menggunakan contoh secara langsung, jadi misalnya materi mufradat tentang pekerjaan seperti menulis, membaca, duduk dll itu saya contohkan atau peragakan kepada siswa, dan siswa memperhatikan apa yang peragakan itu. Dan untuk penilaian hasil belajar biasanya saya melakukan tanya jawab secara langsung setelah selesai penyampaian materi. (wawancara, 21 Agustus 2021).

Dari hasil wawancara di atas dapat dirumuskan bahwa strategi pengajaran bahasa Arab di MI Rakha Amuntai adalah sebagai berikut:

\footnotetext{
8 Saidah Ramadhan, "Strategi Pembelajaran Bahasa Arab pada Anak Usia Dini," Utile: Jurnal Kependidikan 3, no. 2 (2017): 180-89.
}

Al-Madrasah: Jurnal Ilmiah Pendidikan Madrasah Ibtidaiyah Vol. 6, No. 1, Januari-Maret 2022 


\section{Perencanaan Pembelajaran}

Secara bahasa strategi berasal dari bahasa Yunani yaitu strategia yang memiliki makna ilmu perang atau panglima perang. ${ }^{9}$ Namun strategi dalam konteks pengajaran memiliki arti bahwa sebagai haluan garis besar yang menjadi dasar untuk mencapai tujuan sebagaimana yang telah ditentukan dalam pembelajaran. ${ }^{10}$ Strategi adalah perencanaan, langkah dan aturan yang secara implementasinya akan dilaksanakan dari proses pembelajaran dalam rangka mencapai tujuan tertentu. ${ }^{11}$ Menurut Abdul Majid strategi pembelajaran adalah suatu perencanaan yang berisikan tentang rencana aktitvitas belajar mengajar yang dirancang agar tercapainya tujuan Pendidikan tertentu yang isinya mencakup penggunaan metode, pendekatan, teknik, sumber belajar, media, pembagian antar siswa, serta usaha pengukuran terhadap proses, hasil dan efek dari kegiatan pembelajaran. ${ }^{12}$ Oemar Hamalik mempertegas pendapat ini bahwa strategi pembelajaran adalah keseluruhan prosedur dan metode dalam proses kegiatan pembelajaran yang bertujuan untuk mencapai tujuan tertentu. ${ }^{13}$

Hal ini sebagaimana yang telah diktakan oleh Guru bahasa Arab MI Rakha Amuntai,

Biasanya sebelum saya mengajar bahasa arab, saya merencanaan pembelajaran bahasa arab dengan menyusun dan menyiapkan RPP terlebih dahulu, nah dengan RPP itu jadinya semakin mudah mengajarnya.

Dari penjelasan tersebut dapat dipahami bhawa guru bahasa Arab MI Rakha Amuntai dalam melaksanakan pengajaran bahasa Arab terlebih dahulu mempersiapkan, merencanakan dan menyusun langkah-langkah pembelajaran dengan menuangkannya ke dalam RPP. RPP ini merupakan hal sangat utama dalam merencakaan pembelajaran sebelum nantinya pembelajaran dilaksanakan. Dengan kata lain, di dalam RPP telah didesain dan direncakan dengan matang terutama strategi apa yang akan digunakan dalam pengajaran bahasa Arab terutama materi mufradat.

Pada dasarnya salah satu perencanaan yang dipersiapkan oleh pengajar sebelum melaksanakan kegiatan pembelajaran adalah menyusun Rencana Pelaksanaan Pembelajaran (RPP). Jadi bagi setiap guru yang berada pada satuan Pendidikan memiliki kewajiban untuk Menyusun RPP secara komplit, sistematik, dengan tujuan agar pembelajaran bisa berjalan dengan efektif dan mampu mencapai tujuan pembelajaran sesuai yang telah diinginkan. guru ketika menyusun rencana pelaksanaan pembelajaran atau RPP ada hal-hal yang perlu diperhatikan terkait dengan komponen-

9 Anggi Fitri, "Strategi Belajar Bahasa Anak," PENTAS: Pendidikan Bahasa Dan Sastra Indonesia 4, no. 1 (2018): 22-32.

${ }^{10}$ Sapuadi, Strategi Pembelajaran (Palangka Raya: Harapan Cerdas, 2019).

11 Ridwan Laki, "Strategi Pembelajaran Bahasa Indonesia Di Erakurikulum Tingkat Satuan Pendidikan (KTSP)," Guru Tua: Jurnal Pendidikan Dan Pembelajaran 1, no. 1 (2018): 23-29.

12 Abdul Majid, Strategi Pembelajaran (Bandung: PT Remaja Rosdakarya, 2013).

${ }^{13}$ Oemar Hamalik, Proses Belajar Mengajar (Bumi Aksara, 2003). 
komponen pada RPP, yaitu identitas mata pelajaran, standar kompetensi, kompetensi dasar, indicator pencapaian kompetensi, tujuan pembelajaran, alokasi waktu, materi ajar, metode atau pendekatan pembelajaran, kegiatan pembelajaran, sumber belajar, dan penilaian hasil belajar.

2. Pelaksanaan Pembelajaran

Pelaksanaan pembelajaran adalah suatu kegiatan atau aktivitas pembelajaran sebagai bentuk implementaso dari perencanaan pembelajaran. Kegiatan dari pelaksanaan pembelajaran ini meliputi kegiatan pendahuluan (awal), kegiatan inti pembelajaran dan kegiatan akhir (penutup).

Sebagaimana hasil wawancara dengan Guru MI Rakha Amuntai

Jadi saya biasanya mengajar, ada pendahuluan, kegiatan inti atau penyampain materi dan di akhir ada penilaian. Dan saya biasanya ketika mengajar bahasa arab terutama materi mufradat itu biasanya mengajarnya menggunakan contoh secara langsung atau menunjukkan benda yang dimaksud, jadi misalnya materi mufradat tentang pekerjaan seperti menulis, membaca, duduk dll itu saya tunjukkan aktivitas orang yang sedang menulis, dan terkadang saya contohkan atau peragakan kepada siswa, dan siswa memperhatikan apa yang peragakan itu.

Dari hasil wawancara tersebut dapat dipahami bahwa pelaksanaan pembelajaran bahasa Arab materi mufradat diawali dengan adanya pendahuluan, kegiatan utama/inti dan kegiatan penutup/akhir. Adapun strategi guru bahasa Arab yang digunakan untuk mengajarkan materi mufradat adalah menunjukkan bendanya secara langsung, selain itu juga dengan mencontohkan atau memperagakan kepada siswa sesuai dengan mufradatnya. Terlihat langkah-langkah strategi pembelajaran bahasa Arab materi mufradat belum tertulis secara rinci dan sistematis, selain itu metode dan media juga tidak tertulis secara rinci di RPP yang telah disusun, menurutnya hal tersebut bisa saja fleksibel, jadi tidak perlu dituliskan secara rinci di RPP.

Rencana pelaksanaan pembelajaran (RPP) sangat memiliki peran penting dan sangat menunjang dalam hal peningkatan mutu Pendidikan. Perencanaan termasuk strategi sangat dibutuhkan ketika sebelum melaksanakan proses pembelajaran, hal ini tentunya sebagai acuan agar proses pembelajaran terarah dan tersusun sesuai dengan tujuan pembelajaran yang akan dituju dan dicapai pada satuan Pendidikan. Perlu untuk diketahui bahwa RPP merupakan rancangan pelaksanaan pembelajaran per pertemuan yang akan diimplementasikan oleh guru dalam belajar mengajar di dalam kelas. Dalam penyusunan (RPP) ini seharusnya guru bisa mengimplmentasikan belajar mengajar yang lebih baik dan menghasilkan pembelajaran yang berkualitas. Tanpa persiapan dan strategi yang matang, maka mustahil dan sangat kecil kemungkinan pembelajaran bisa tercapai maksimal. Oleh karena itu, secara teknik perencanaan pembelajaran setidaknya mencakup komponen-komponen sebagai berikut, yaitu standar kompetensi, kompetensi dasar, dan indicator pencapaian belajar, tujuan belajar mengajar, materi pembelajaran, strategi, pendekatan dan metode pembelajaran, sintak proses kegiatan pembelajaran, sumber dan alat belajar, dan evaluasi pembelajaran. Namun, masih ditemukan bahwa Sebagian guru menganggap suatu 
perencanaan pembelajaran terlalu konseptual, dan pada kenyataan dalam pembelajaran hal tersebut tidak relevan, sehingga sebagiang guru malas untuk membuat perencanaan tersebut. ${ }^{14}$

Menurut Mustofa strategi pembelajaran bahasa mufradat bahasa Arab jika dilihat pada tingkatan, maka terklasifikasikan kepada tiga tingkatan, yaitu tingkat dasar, menengah, dan lanjutan. Adapun pada strategi pembelajaran mufradat pada tingkatan mubtadi'/dasar guru dapat melakukan dengan nyanyian/lagu, menunjukkan benda aslinya atau benda sampelnya, memerintahkan siswa untuk membacanya secara berulang kali, dan memperdengarkan dan mengikuti bacaan dan mengulamh bacaan disertai dengan menulis sampai siswa menguasai dan paham. ${ }^{15}$

Adapun pada tingkat menengah guru dapat melakukan dengan menggunakan suatu Gerakan tubuh untuk menunjukkan dan mencontohkan makna pada suatu mufradat bahasa Arab, menuliskan kata-kata atau mufradat, dengan begitu siswa akan mudah dan merasa terbantu dengan kegiatan tersebut. Dengan bermain peran, memberikan sinonimya, memberikan antonimnya, memberikan asosiasi makna, dan guru menyebutkan kata yang telah berubah atau terjadi perbuahan dan akar katanya, hal ini tentunya bisa menolong peserta didik untuk memudahkan memahami mufarat yang sesuai dengan kalimat yang mengalami perubahan. Sedangkan pada tingkat lanjutan, strategi dalam pembelajaran dapat dilalui dengan menjabarkan maksud dan maknanya, mencari makna setiap kata yang berada di kamus, memisah-misahkan (mengacak) kosakata agar menjadi suatu kesatuan kata yang baik dan benar, memasukkan kata pada suatu jumlah/kalimat, menuangkan baris/harakat pada kata. ${ }^{16}$

3. Penilaian hasil pembelajaran

Penilaian merupakan serangkaian kegiatan pemeriksaan secara berkelanjutan terhadap semua informasi yang berhubungan dengan semua kegiatan pembelajaran, program pembelajaran, Pendidikan dan siswa untuk mengetahui sejauhmana program pembelajaran sudah mencapai tujuan yang telah ditentunkan dan untuk mengatahui tingkat perubahan tingkah laku peserta didik setelah proses pembelajaran dilaksanakan. ${ }^{17}$ Menurut Gronlund penilaian adalah sutau proses mengumpulkan, menganalisis, dan mengartikan dan menjabarkan informasi sehingga dengan begitu dapat menentukan dan menetapkan sejauhmana siswa telah mencapai tujuan belajar

${ }^{14}$ Isnawardatul Bararah, "Efektifitas Perencanaan Pembelajaran dalam Pembelajaran Pendidikan Agama Islam di Sekolah,” Jurnal MUDARRISUNA: Media Kajian Pendidikan Agama Islam 7, no. 1 (2017): $131-47$.

15 Bararah, 131-47.

${ }^{16}$ Ramli Abdullah, "Urgensi Penilaian Hasil Belajar Berbasis Kelas Mata Pelajaran IPS di Madrasah Tsanawiyah,” Lantanida Journal 3, no. 2 (2017): 168-81.

17 Abdullah.

Al-Madrasah: Jurnal Ilmiah Pendidikan Madrasah Ibtidaiyah Vol. 6, No. 1, Januari-Maret 2022 
mengajar. ${ }^{18}$ Hal ini dipertegas oleh Isaac dan Michael yang menyatakan bahwa kesuksesan suatu pekerjaan seseorang dapat diketahui dari hasil melakukan penilaian, dengan melakukan penilaian suatu kegiatan berhasil atau tidak dapat diketahui, setelah hal tersebut dapat diketahui sehingga informasi yang telah dikumpulkan, dianalisis dan memeriksa, dan memanfaatkannya hal tersebut untuk dapat dijadikan sebagai bahan pertimbangan untuk mengambil suatu keputusan. ${ }^{19}$

Hal ini sebagaimana yang dikatakan oleh Guru MI Rakha Amuntai,

Dan untuk penilaian hasil belajar biasanya saya melakukan tanya jawab secara langsung setelah selesai penyampaian materi.

Dari pernyataan tersebut dapat dipahami bahwa guru setelah selesai menyampaikan materi pembelajaran selanjutnya adalah guru melakukan penilaian hasil belajar dilakukan dengan lisan atau tanya jawab secarra langsung. Berdasarkan observasi penulis, terlihat guru memberikan pertanyaan tentang mufradat yang telah disampaikan dengan menunjuk suatu benda, kemudian apa bahasa arabnya dari benda tersebut, begitupun sebaliknya, guru menyebutkan bahasa arabnya, kemudian siswa menyebutkan artinya.

Hasil penilaian belajar dimanfaatkan guru dan sekolah untuk mengetahui kekurangan dan kelebihan peserta didik pada satu sekolah dan kelas pada mata pelajaran semuanya. Dengan begitu guru harus dapat terbantu dengan adanya hasil penilaian pembelajaran, sehingga dapat digunakan sebagai bahan perbaikan baik dari segi penggunaan strategi, perlengkapan fasilitas pembelajaran, dan pada intinya dapat membantu guru dan sekolah agar dapat melaksanakan pembelajaran dengan lebih baik lagi. ${ }^{20}$

Menurut Sardiman kemampuan pendidik dalam melaksanakan penilaian hasil belajar peserta didik adalah kemampuan menilai/mengukur berubahnya tingkah laku peserta didik selama kegiatan belajar mengajar berlangsung, dan juga mampu menilai kemampuan dirinya sendiri yang berkaitan dengan merencana, melaksanakan, dan menilai hasil pembelajaran. ${ }^{21}$ Senada yang dinyatakan oleh Purwanto yang menyatakan bahwa hasil pembelajaran adalah perkembangan dan kemajuan peserta didik sesudah melaksanakan kegiatan yang dapat mengubah tingkah lakunya secara menyeluruh, sebagai hasil dari pengalaman pribadinya yang telah berinteraksi dengan lingkungannya. ${ }^{22}$

\footnotetext{
${ }^{18}$ Norman Gronlund, Meassurement and Evaluation in Teaching (New York: Mac Milan Publishing Company, 1985), h. 5.

${ }^{19}$ Stephen Isaac dan William B. Michael, Handbook in Research and Evaluation (Sandiego: Edits Publisher, 1981), h. 2. Tsanawiyah."

${ }^{20}$ Abdullah, "Urgensi Penilaian Hasil Belajar Berbasis Kelas Mata Pelajaran IPS di Madrasah

${ }^{21}$ Arief M Sardiman, Interaksi dan Motivasi Belajar Mengajar (Jakarta: Raja Grafindo Persada, 2020), h. 174. 2009), h. 5.

${ }^{22}$ M. Ngalim Purwanto, Prinsip-Prinsip Evaluasi Pengajaran (Bandung: PT Remaja Rosdakarya,
}

Al-Madrasah: Jurnal Ilmiah Pendidikan Madrasah Ibtidaiyah

Vol. 6, No. 1, Januari-Maret 2022 
Dari pendapat tersebut dapat dipahami bahwa pembelajaran/belajar mengajar pada akhirnya akan menciptakan kemampuan pada seseorang baik kemampuan keterampilan, pengetahuan, dan berubahnya perilaku yang terjadi pada kemampuan seseorang tersebut, dan hal hal itulah yang menjadi tolak ukur untuk mengetahui hasil pembelajaran siswa. ${ }^{23}$ Sehingga dapat dapat diketahui bahwa yang menentukan kemampuan pada seseorang adalah baik kemampuan pengetahuan, keterampilan dan perubahan sikap dapat terjadi berdasarkan hasil kegiatan proses belajar mengajar, oleh karena itu perencaaan yang matang, proses pembelajaran yang baik, dan penilaian hasil belajar yang tepat akan menghasilkan pembelajaran yang berkualitas.

\section{SIMPULAN}

Dari uraian di atas dapat disimpulkan bahwa strategi pengajaran bahasa Arab pada materi mufradat di MI Rakha Amuntai sudah berjalan dengan baik. Hal ini dibuktikan dengan adanya penyusunan perencanaan pelaksanaan pembelajaran dengan baik, setidaknya sudah tersusun dan tergambarkan proses pembelajaran mulai dari pendahuluan, kegiatan inti dan penutup. Namun begitu, dalam perencanaan tersebut belum tergambarkan secara jelas terkait strategi apa yang digunakan, serta langkah-langkahnya juga belum tersusun secara terperinci, begitu juga dengan metode dan medianya. Namun guru terlihat menggunakan strategi bermain peran dan demonstrasi dalam mengajarkan bahasa Arab pada materi mufradat di MI Rakha Amuntai.

Secara teoretis dan praktis penelitian ini diharapkan dapat memberi masukan dan kontribusi bagi sekolah dan guru, agar mempersiapkan rencana pembelajaran dengan sebaik-baiknya, melengkapai komponen-komponen pada perencanaan pelaksanaan pembelajaran, dan menentukan strategi, metode, pendekatan, dan media yang tepat untuk materi pelajaran yang akan disampaikan kepada siswa, sehingga materi menjadi lebih mudah diserap dan kuasai oleh siswa dan tujuan pembelajaran dapat tercapai dengan maksimal.

\section{DAFTAR PUSTAKA}

Abdullah, Ramli. "Urgensi Penilaian Hasil Belajar Berbasis Kelas Mata Pelajaran IPS di Madrasah Tsanawiyah.” Lantanida Journal 3, no. 2 (2017): 168-81.

Asse, Ahmad, dan Nursyam Nursyam. "Strategi Pembelajaran Bahasa Arab di Insutut Agama Islam Negeri Palu." Istiqra: Jurnal Hasil Penelitian 2, no. 2 (2014): 450-71.

Bararah, Isnawardatul. "Efektifitas Perencanaan Pembelajaran dalam Pembelajaran Pendidikan Agama Islam di Sekolah.” Jurnal MUDARRISUNA: Media Kajian Pendidikan Agama Islam 7, no. 1 (2017): 131-47.

Fitri, Anggi. "Strategi Belajar Bahasa Anak." PENTAS: Pendidikan Bahasa Dan Sastra Indonesia 4, no. 1 (2018): 22-32. Tsanawiyah."

${ }^{23}$ Abdullah, "Urgensi Penilaian Hasil Belajar Berbasis Kelas Mata Pelajaran IPS di Madrasah

Al-Madrasah: Jurnal Ilmiah Pendidikan Madrasah Ibtidaiyah

Vol. 6, No. 1, Januari-Maret 2022 
Gronlund, Norman. Meassurement and Evaluation in Teaching. New York: Mac Milan Publishing Company, 1985.

Hamalik, Oemar. Proses Belajar Mengajar. Bumi Aksara, 2003.

Isaac, Stephen, dan William B. Michael. Handbook in Research and Evaluation. Sandiego: Edits Publisher, 1981.

KBBI Offline versi 1.2, t.t.

Khansa', Hasna Qunita. "Strategi Pembelajaran Bahasa Arab." Proseding Konferensi Nasional Bahasa Arab 1, no. 2 (2016).

Khotijah, Khotijah. "Desain Strategi Pembelajaran Bahasa Arab Di MI." Al-Fathin: Jurnal Bahasa dan Sastra Arab 1, no. 01 (2018): 22-36.

Laki, Ridwan. "Strategi Pembelajaran Bahasa Indonesia Di Erakurikulum Tingkat Satuan Pendidikan (KTSP)." Guru Tua: Jurnal Pendidikan Dan Pembelajaran 1, no. 1 (2018): 23-29.

Majid, Abdul. Strategi Pembelajaran. Bandung: PT Remaja Rosdakarya, 2013.

Purwanto, M. Ngalim. Prinsip-Prinsip Evaluasi Pengajaran. Bandung: PT Remaja Rosdakarya, 2009.

Ramadhan, Saidah. "Strategi Pembelajaran Bahasa Arab pada Anak Usia Dini." Utile: Jurnal Kependidikan 3, no. 2 (2017): 180-89.

Sapuadi. Strategi Pembelajaran. Palangka Raya: Harapan Cerdas, 2019.

Saputro, Suprihadi, Zainul Abidin, dan I Wayan Sutama. Strategi Pembelajaran, Bahan Sajian Program Pendidikan Akta Mengajar. Malang: Universitas Negeri Malang, 2002.

Sardiman, Arief M. Interaksi dan Motivasi Belajar Mengajar. Jakarta: Raja Grafindo Persada, 2020.

Slameto. Proses Belajar Megajar Dalam Sistim Kredit Semester. Jakarta: Bumi Aksara, 1991.

Al-Madrasah: Jurnal Ilmiah Pendidikan Madrasah Ibtidaiyah

Vol. 6, No. 1, Januari-Maret 2022 